\title{
THE USE OF SEWAGE SLUDGE AND
}

\section{DIATOMITE AS GROWING MEDIUM IN SCOTS PINE (PINUS SYLVESTRIS L.) SEEDLING PRODUCTION AND EVALUATION OF ITS LAND PERFORMANCE}

\author{
KORIŠTENJE OTPADNOG MULJA I DIATOMITA KAO MEDIJA \\ U PROIZVODNJI SADNICA OBIČNOG BORA (Pinus sylvestris L.) \\ I PROCJENA PREŽIVLJAVANJA SADNICA NA TERENU
}

Murat KOSE ${ }^{1 *}$, Caglar UGURLU' ${ }^{1}$, Omer ONCUL ${ }^{1}$, Fatih DEMIRCI ${ }^{1}$, Ilker ANGIN²

\begin{abstract}
SUMIMARY
Although several organic and inorganic substrates are added to growing media for improving its physical and chemical characteristics, the need for search of new materials and/or mixtures that reduces the high-priced peat content in substrates is still interesting. This study evaluated the feasibility of reducing the peat content in substrates by replacing it with different amounts of diatomite and sewage sludge for Scots pine seedling (Pinus sylvestris L.) growth and their land performance. In order to evaluate the feasibility of reducing the peat content in substrates by replacing it with different amounts of diatomite and sewage sludge, an experiment was carried out in a temperature-controlled greenhouse under natural light. To evaluate the land performance of Scots pine seedlings grown in different substrates, a trial was established between the years 2013-2017 in Sarıkamıs, Kars (NE Anatolia). Sewage sludge application, due to its high organic matter and macro and micronutrient content, has improved the composition of the rhizosphere, thereby resulting in growth acceleration. As a result of the evaluations made in terms of both seedling morphological characteristics and land performance; the best performance was determined in the $9^{\text {th }}(50 \% \mathrm{P}+50 \% \mathrm{SS})$ and $3^{\text {rd }}(75 \% \mathrm{SS}+25 \% \mathrm{DE})$ mixtures.
\end{abstract}

KEY WORDS: Sewage sludge, diatomite, peat, scots pine, morphological properties, land performance

\section{INTRODUCTION}

\section{UVOD}

Several organic (peat, sawdust, bark, wood chips, etc.) and inorganic (pumice, zeolite, vermiculite, etc.) substrates are added to growing media for improving its physical and chemical characteristics, which promote plant growth. Since the growing medium relates to every cultural practice in the production of nursery crops, selection and/or formulation of medium is of great importance for sustainable production. A well-chosen growing media and media components should supply a high nutrient-holding capacity, desirable water holding and aeration characteristics, a good decomposition rate (C:N), lightweight, an electrical conductivity (EC) within range of $0.5-3.0 \mathrm{dS} \mathrm{m}^{-1}$, and a neutral pH (Csaba 1995; Olympios 1999; Ingram et al. 2003; Angin

' Dr. Murat Kose, MSc. Caglar Ugurlu, Dr. Omer Oncul, MSc: Fatih Demirci, Caglar Ugurlu, Omer Oncul, Fatih Demirci, Eastern Anatolia Forestry Research Institute, 25050, Erzurum, Turkey

${ }_{2}^{2}$ Prof. Dr. Ilker Angin, Department of Agricultural Structures and Irrigation, Faculty of Agriculture, Atatürk University, 25240, Erzurum, Turkey 
et al. 2011). To satisfy higher yields and quality, it is important to find a substrate or substrate mixtures with a good performance. Therefore, there is a need for search of new materials and/or mixtures that reduces the high-priced peat content in substrates.

Diatomite (Diatomaceous Earth or DE) is a sedimentary rock primarily composed of the fossilized remains of unicellular freshwater plants known as "diatoms". Diatomite contains up to $80-90 \%$ voids (Khraisheh et al. 2004) and has a large surface area of 50-200 $\mathrm{m}^{2} \mathrm{~g}^{-1}$ (Wu et al. 2005). Diatomite consists of approximately $90 \%$ silicon dioxide, which is absorbed into plant tissues and helps to improve plant structure and resistance to pests and diseases. The remainder of its being elemental minerals, which are essential for plant growth (USGS 2008). Recent studies conducted by Aksakal et al. $(2012,2013)$ have indicated that diatomite might be an alternative soil amendment agent for improving soil physical and mechanical characteristics. Angin et al. (2011) have studied the effects of diatomite on the growth of strawberry and find out that diatomite application not only improved hydro-physical properties of soil but also vegetative parameters of strawberry. All of abovementioned features and conducted studies have shown that diatomite can be used as an alternative substrate for peat. However, the most limiting factor for its use as a growing media is its organic matter content, which is relatively low.

Sewage sludge is a concentrated suspension of solids, largely composed of organic compounds, plant nutrients, trace elements, inorganic materials, and pathogens (Epstein 2003). The organic nature of sewage sludge, along with plant nutrients and several trace elements, shows that it has great potential for improving soil fertility and crop productivity. The potential outlets commonly considered for sewage sludge use and disposal can be classified as; landbased, product-based, energy recovery, and landfill disposal. The preferred and common management option for sewage sludge is beneficial to use on land, particularly for agricultural production and forestry. Use in this way not only ensures that nutrients and organic matter are recycled to the soil to enhance crop production but also reduces the use of chemical fertilizers. In Turkey, more than 1 million tonnes of sewage sludge is generated each year (Aslantas et al. 2013). Using sewage sludge as a substrate could be a feasible option, especially not only for the protection of the environment but also for decreasing the fertilizer cost. The positive effect of sewage sludge usage as a substitute for peat and soil has been reported by several studies (Raviv et al. 1986; Pinamonti et al. 1997; Ingelmo et al. 1998; Perez-Murcia et al. 2006; Jayasinghe et al. 2010; Méndez et al. 2017). However, its usage along with diatomite as a media component for nursery growth is not investigated yet.
This study was undertaken to evaluate (a) the feasibility of reducing the peat content in substrates by replacing it with different amounts of diatomite and sewage sludge for Scots pine seedling (Pinus sylvestris L.) growth and (b) evaluation of the land performance of Scots pine seedlings grown in different substrates.

\section{MATERIALS AND METHODS MATERIJALI I METODE}

In order to evaluate the feasibility of reducing the peat content in substrates by replacing it with different amounts of diatomite and sewage sludge, an experiment was carried out in a temperature-controlled greenhouse under natural light, from 11 April to 22 October 2013, in Erzurum Forestry Research Station, Turkey $\left(39^{\circ} 55^{\prime} \mathrm{N}, 41^{\circ} 61^{\prime} \mathrm{E}\right)$. The temperature in the greenhouse was set to $24 \pm 2^{\circ} \mathrm{C}$ and $18 \pm 2^{\circ} \mathrm{C}$ during day and night, respectively. Diatomite (DE) and sewage sludge (SS) passed through 8-mm sieve was applied along with or without peat $(\mathrm{P})$ within the rates $(v / v)$ of $100 \% S S(1) ; 25 \% S S+75 \% D E(2) ; 75 \% S S+25 \% D E(3)$; $50 \% S S+50 \% D E(4) ; 25 \% P+75 \% D E(5) ; 25 \% P+75 \% S S(6)$; $25 \% P+50 \% D E+25 \% S S$ (7); $25 \% P+25 \% D E+50 \% S S(8)$; $50 \% P+50 \% S S \quad(9) ; \quad 50 \% P+25 \% D E+25 \% S S \quad(10)$; $50 \% P+50 \% D E$ (11); 75\%P+25\%DE (12); 75\%P+25\%SS (13); $100 \% P(14$, Control); and $100 \% D E(15)$. General characteristics of the materials used in this study are given in Table 1. pH and electrical conductivity measurements were carried out according to Thomas (1996) and Rhoades (1996). Organic matter was determined using the SmithWeldon method (Nelson and Sommers 1996). Lime content of the substrates was determined with the 'Scheibler Calcimeter' as described in Loeppert and Suarez (1996). A wavelength dispersive X-ray fluorescence spectrometer from Rigaku (ZSX-100e, Rigaku Industrial Corporation, Japan) was used to determine the chemical components of substrates.

Mixtures with defined amounts were conveyed to seedling trays, with an internal cell volume of $190 \mathrm{cc}$. The used Scots pine (Pinus sylvestris L.) seeds were "Sarıkamış" originated. Two seeds were sown per cell and after 5 days of sowing, they were thinned to one seedling. The experiment was set up in a randomized block design with 15 mixtures and with three replications, as a total of 1170 seeds ( 15 mixture $\times 26$ Scots pine seeds $\times 3$ replications). No pesticide and fertilizer were applied throughout the experiment. At the end of the experiment (22 October 2013) 10 seedlings from each replication were collected and analyzed for the determination of height, stem diameter, and shoot and root dry weight. Dickson Quality Index (QI) was calculated from the obtained values according to Dickson et al (1960).

To evaluate the land performance of Scots pine seedlings grown in different substrates, a trial was established be- 
Table 1. Initial characteristics of materials used in this study Tablica 1. Početna svojstva materijala korištenih u istraživanju

\begin{tabular}{|c|c|c|c|c|}
\hline \multicolumn{2}{|c|}{$\begin{array}{l}\text { Parameters } \\
\text { (Parametri) }\end{array}$} & $\begin{array}{c}\text { Sewage } \\
\text { Sludge (SS) } \\
\text { (Mulj iz } \\
\text { otpadnih voda) }\end{array}$ & $\begin{array}{c}\text { Diatomite (DE) } \\
\text { (Diatomit) }\end{array}$ & $\begin{array}{l}\text { Peat (P) } \\
\text { (Treset) }\end{array}$ \\
\hline \multicolumn{2}{|c|}{$\mathrm{pH}$} & $6.23(1: 10)$ & $6.81(1: 2.5)$ & $5.20(1: 2.5)$ \\
\hline \multicolumn{2}{|c|}{$\mathrm{EC}\left(\mathrm{mS} \mathrm{cm} \mathrm{cm}^{-1}\right)$} & $1.23(1: 10)$ & $0.31(1: 2.5)$ & $0.27(1: 2.5)$ \\
\hline \multicolumn{2}{|c|}{$\begin{array}{l}\text { Lime (\%) } \\
\text { (Vapno) }\end{array}$} & 1.23 & 0.94 & - \\
\hline \multicolumn{2}{|c|}{$\begin{array}{l}\text { Organic Matter (\%) } \\
\text { (Organska tvar) }\end{array}$} & 43.54 & 0.72 & 93 \\
\hline \multirow{20}{*}{ 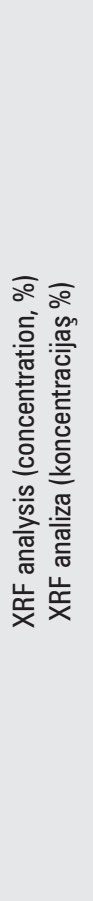 } & 0 & 47.62 & 50.43 & 38.93 \\
\hline & C & 16.91 & 3.29 & 57.29 \\
\hline & $\mathrm{Ca}$ & 13.18 & 2.18 & 2.31 \\
\hline & $\mathrm{Si}$ & 9.44 & 31.74 & 0.41 \\
\hline & $\mathrm{Al}$ & 3.54 & 7.85 & 0.13 \\
\hline & $P$ & 2.27 & 0.24 & 0.09 \\
\hline & S & 2.21 & 0.04 & 0.26 \\
\hline & $\mathrm{Fe}$ & 1.81 & 1.57 & 0.08 \\
\hline & $\mathrm{Mg}$ & 1.25 & 1.14 & 0.20 \\
\hline & K & 0.96 & 0.42 & 0.27 \\
\hline & $\mathrm{Zn}$ & 0.31 & 0.01 & $<0.01$ \\
\hline & $\mathrm{Na}$ & 0.23 & 0.59 & - \\
\hline & $\mathrm{Ti}$ & 0.17 & 0.43 & - \\
\hline & $\mathrm{Mn}$ & 0.04 & - & - \\
\hline & $\mathrm{Cu}$ & 0.02 & - & - \\
\hline & $\mathrm{Sr}$ & 0.02 & 0.02 & - \\
\hline & $\mathrm{Ni}$ & $<0.01$ & - & - \\
\hline & V & - & 0.04 & - \\
\hline & $\mathrm{Pd}$ & - & 0.02 & - \\
\hline & $\mathrm{Cl}$ & - & - & 0.04 \\
\hline
\end{tabular}

tween the years 2013-2017 in Sarıkamış, Kars (NE Anatolia). The study area is dominated by a continental climate (with an average altitude of $2250 \mathrm{~m}$ ), with long winters and short summers. The mean annual minimum and maximum temperatures, relative humidity, and total precipitation are: -8.1 and $15.6^{\circ} \mathrm{C}, 67 \%$, and $575 \mathrm{~mm}$, respectively. Soils of the experimental site are of volcanic origin and have low $\mathrm{CaCO}_{3}$ content. Seedlings grown in the greenhouse were transplanted to the study area in a randomized block design with three repetitions, as a total of 672 seedlings (14 mixture $\times 16$ Scots pine seedlings $\times 3$ replications) (No plant growth was observed in $100 \% \mathrm{DE}$, cancelled). They were planted at $1.5 \times 3 \mathrm{~m}$ on 23 October 2013. Survival rates and height and stem diameter of seedlings were measured in the fall of 2017. Height and stem diameters of the seedlings were measured from the soil surface.

All the data were subjected to analysis of variance (ANOVA) and the significant means were compared by Duncan's multiple comparison test method, performed using the SPSS Statistical Package v.20.0 (IBM 2011) at $\mathrm{p} \leq 0.05$ level of significance, unless otherwise mentioned.

\section{RESULTS REZULTATI}

Effects of growing media on Scots pine seedlings (Pinus sylvestris $\mathrm{L}$.) morphological properties are presented in Table 2. Height of Scots pine seedlings varied between 3.75-6.37 $\mathrm{cm}$. The highest growth was observed in $6^{\text {th }}, 1^{\text {st }}, 9^{\text {th }}, 13^{\text {th }}$, and $10^{\text {th }}$ mixtures. As compared with the control $\left(14^{\text {th }}\right.$ mixture),

Table 2. Effects of growing media on Scots pine seedlings (Pinus sylvestris L.) morphological properties Tablica 2. Utjecaj supstrata za rast na morfološka svojstva sadnica običnog bora (Pinus sy/vestris L.)

\begin{tabular}{clcccc}
$\begin{array}{c}\text { Substrates } \\
\text { (Supstrati) }\end{array}$ & $\begin{array}{c}\text { Height }(\mathrm{cm}) \\
\text { (Visina) }\end{array}$ & $\begin{array}{c}\text { Diameter }(\mathrm{mm}) \\
\text { (Promjer) }\end{array}$ & $\begin{array}{c}\text { Dry weight }(\mathrm{g}) \\
\text { (Ukupna biomasa u suhom stanju) } \\
\text { Shoot (Stabljika) }\end{array}$ & $\begin{array}{c}\text { Dickson Quality Index (Ol) } \\
\text { (Dicksonov index kvalitete) }\end{array}$ \\
\hline 1 & $6.23 \pm 0.29 \mathrm{a} \mathrm{a}^{\psi}$ & $1.07 \pm 0.02 \mathrm{a}$ & $0.27 \pm 0.01 \mathrm{a}$ & $0.24 \pm 0.05 \mathrm{ab}$ & $0.074 \pm 0.013 \mathrm{~b}$ \\
2 & $5.04 \pm 0.22 \mathrm{ef}$ & $0.97 \pm 0.03 \mathrm{c}$ & $0.12 \pm 0.01 \mathrm{de}$ & $0.15 \pm 0.01 \mathrm{de}$ & $0.046 \pm 0.002 \mathrm{~cd}$ \\
3 & $5.41 \pm 0.39 \mathrm{de}$ & $1.07 \pm 0.02 \mathrm{a}$ & $0.23 \pm 0.01 \mathrm{~b}$ & $0.27 \pm 0.02 \mathrm{a}$ & $0.085 \pm 0.002 \mathrm{a}$ \\
4 & $4.83 \pm 0.17 \mathrm{f}$ & $0.87 \pm 0.02 \mathrm{e}$ & $0.10 \pm 0.01 \mathrm{ef}$ & $0.10 \pm 0.01 \mathrm{fg}$ & $0.031 \pm 0.003 \mathrm{ef}$ \\
5 & $3.75 \pm 0.13 \mathrm{~g}$ & $0.56 \pm 0.04 \mathrm{f}$ & $0.04 \pm 0.01 \mathrm{~g}$ & $0.05 \pm 0.01 \mathrm{~h}$ & $0.011 \pm 0.001 \mathrm{~g}$ \\
6 & $6.37 \pm 0.20 \mathrm{a}$ & $0.99 \pm 0.04 \mathrm{bc}$ & $0.20 \pm 0.01 \mathrm{c}$ & $0.16 \pm 0.01 \mathrm{de}$ & $0.046 \pm 0.003 \mathrm{~cd}$ \\
7 & $5.32 \pm 0.12 \mathrm{de}$ & $0.91 \pm 0.04 \mathrm{de}$ & $0.12 \pm 0.02 \mathrm{def}$ & $0.12 \pm 0.02 \mathrm{efg}$ & $0.034 \pm 0.006 \mathrm{ef}$ \\
8 & $5.72 \pm 0.03 \mathrm{bcd}$ & $1.00 \pm 0.05 \mathrm{bc}$ & $0.20 \pm 0.02 \mathrm{c}$ & $0.18 \pm 0.04 \mathrm{~cd}$ & $0.054 \pm 0.012 \mathrm{c}$ \\
9 & $6.12 \pm 0.58 \mathrm{ab}$ & $1.05 \pm 0.04 \mathrm{ab}$ & $0.24 \pm 0.03 \mathrm{~b}$ & $0.21 \pm 0.03 \mathrm{bc}$ & $0.066 \pm 0.007 \mathrm{~b}$ \\
10 & $5.93 \pm 0.19 \mathrm{abc}$ & $0.96 \pm 0.01 \mathrm{~cd}$ & $0.14 \pm 0.01 \mathrm{~d}$ & $0.12 \pm 0.01 \mathrm{ef}$ & $0.036 \pm 0.001 \mathrm{de}$ \\
11 & $5.60 \pm 0.04 \mathrm{~cd}$ & $0.98 \pm 0.06 \mathrm{c}$ & $0.11 \pm 0.01 \mathrm{def}$ & $0.10 \pm 0.02 \mathrm{fg}$ & $0.032 \pm 0.005 \mathrm{ef}$ \\
12 & $5.33 \pm 0.19 \mathrm{de}$ & $0.93 \pm 0.01 \mathrm{~cd}$ & $0.09 \pm 0.01 \mathrm{f}$ & $0.08 \pm 0.01 \mathrm{gh}$ & $0.024 \pm 0.003 \mathrm{f}$ \\
13 & $6.10 \pm 0.30 \mathrm{ab}$ & $0.95 \pm 0.05 \mathrm{~cd}$ & $0.17 \pm 0.03 \mathrm{c}$ & $0.14 \pm 0.03 \mathrm{def}$ & $0.041 \pm 0.008 \mathrm{de}$ \\
14 & $5.09 \pm 0.06 \mathrm{ef}$ & $1.00 \pm 0.02 \mathrm{bc}$ & $0.13 \pm 0.01 \mathrm{~d}$ & $0.10 \pm 0.01 \mathrm{fg}$ & $0.037 \pm 0.004 \mathrm{de}$
\end{tabular}

${ }^{*} 1=100 \% S S ; 2=25 \% S S+75 \% D E ; 3=75 \% S S+25 \% D E ; 4=50 \% S S+50 \% D E ; 5=25 \% P+75 \% D E ; 6=25 \% P+75 \% S S ; 7=25 \% P+50 \% D E+25 \% S S ; 8=25 \% P+25 \% D E+50 \% S S$; $9=50 \% P+50 \% S S ; 10=50 \% P+25 \% D E+25 \% S S ; 11=50 \% P+50 \% D E ; 12=75 \% P+25 \% D E ; 13=75 \% P+25 \% S S ; 14=100 \% P$ (Control); and $15=100 \% D E$

$\psi$ Lowercase letters in columns show differences between substrates 
these mixtures increased seedling height in the rates of $25.1 \%, 22.4 \%, 20.2 \%, 19.8 \%$, and $16.5 \%$, respectively. The rate of sewage sludge in these mixtures varied between 25 $100 \%$, and the highest growths were observed in mixtures with $75 \%-100 \%$ sewage sludge.

In addition to seedling height, application of sewage sludge to growing media also affected the stem diameter of the seedlings significantly. The stem diameter of Scots pine seedlings varied between $0.56-1.07 \mathrm{~mm}$. The highest stem diameters were observed in $1^{\text {st }}, 3^{\text {rd }}$, and $9^{\text {th }}$ mixtures. As compared with the control ( $14^{\text {th }}$ mixture), these mixtures increased stem diameter in the rates of $7 \%, 7 \%$, and $5 \%$, respectively. As in seedling height, the highest stem diameters were observed in mixtures in which sewage sludge was applied.

Shoot and root dry weight measurements also demonstrated some differences in plant development during the experimental growth period. The shoot and root weight of Scots pine seedlings varied between $0.04-0.27 \mathrm{~g}$ and $0.05-0.27 \mathrm{~g}$, respectively. For both of the measured parameters, the highest values were obtained from $1^{\text {st }}, 9^{\text {th }}$, and $3^{\text {rd }}$ mixtures. The rate of sewage sludge in these mixtures varied between 50-100\%. The lowest values were obtained in mixtures were the diatomite was added in $75 \%$.

The maximum values for Dickson Quality Index (QI) are desirable. The QI of Scots pine seedlings varied between 0.011-0.085. Among the substrates tested, sewage sludge

Table 3. Land performance of Scots pine seedlings (Pinus sylvestris L.) grown on different substrates

Tablica 3. Preživljavanje sadnica običnog bora (Pinus sylvestris L.) uzgojenih u različitim supstratima

\begin{tabular}{cccc}
$\begin{array}{c}\text { Substrates } \\
\text { (Supstrati) }\end{array}$ & $\begin{array}{c}\text { Survival Rate } \\
\text { (Postotak } \\
\text { preživljavanja) }\end{array}$ & $\begin{array}{c}\text { Height }(\mathrm{cm}) \\
\text { (Visina) }\end{array}$ & $\begin{array}{c}\text { Diameter }(\mathrm{cm}) \\
\text { (Promjer) }\end{array}$ \\
\hline 1 & $0.83 \mathrm{ab}{ }^{\psi}$ & $33.82 \mathrm{bc}$ & $0.88 \mathrm{cde}$ \\
2 & $0.73 \mathrm{bc}$ & $32.42 \mathrm{~cd}$ & $0.92 \mathrm{~cd}$ \\
3 & $0.96 \mathrm{a}$ & $39.65 \mathrm{a}$ & $1.07 \mathrm{~b}$ \\
4 & $0.90 \mathrm{ab}$ & $27.91 \mathrm{de}$ & $0.83 \mathrm{de}$ \\
5 & $0.65 \mathrm{c}$ & $19.64 \mathrm{~g}$ & $0.64 \mathrm{f}$ \\
6 & $0.94 \mathrm{a}$ & $34.66 \mathrm{bc}$ & $0.88 \mathrm{cde}$ \\
7 & $0.73 \mathrm{bc}$ & $31.85 \mathrm{~cd}$ & $0.89 \mathrm{cde}$ \\
8 & $0.81 \mathrm{ab}$ & $32.17 \mathrm{~cd}$ & $0.98 \mathrm{bc}$ \\
9 & $0.90 \mathrm{ab}$ & $41.58 \mathrm{a}$ & $1.18 \mathrm{a}$ \\
10 & $0.94 \mathrm{a}$ & $31.46 \mathrm{cde}$ & $0.87 \mathrm{cde}$ \\
11 & $0.81 \mathrm{ab}$ & $28.71 \mathrm{de}$ & $0.88 \mathrm{cde}$ \\
12 & $0.83 \mathrm{ab}$ & $26.62 \mathrm{e}$ & $0.84 \mathrm{de}$ \\
13 & $0.83 \mathrm{ab}$ & $28.42 \mathrm{de}$ & $0.77 \mathrm{e}$ \\
14 & $0.92 \mathrm{a}$ & $37.45 \mathrm{ab}$ & $1.05 \mathrm{~b}$ \\
15 & Cancelled-No plant growth was observed
\end{tabular}

$* 1=100 \% S S ; 2=25 \% S S+75 \% D E ; 3=75 \% S S+25 \% D E ; 4=50 \% S S+50 \% D E ;$ $5=25 \% \mathrm{P}+75 \% \mathrm{DE} ; \quad 6=25 \% \mathrm{P}+75 \% \mathrm{SS} ; \quad 7=25 \% \mathrm{P}+50 \% \mathrm{DE}+25 \% \mathrm{SS}$; $8=25 \% \mathrm{P}+25 \% \mathrm{DE}+50 \% \mathrm{SS} ; 9=50 \% \mathrm{P}+50 \% \mathrm{SS} ; 10=50 \% \mathrm{P}+25 \% \mathrm{DE}+25 \% \mathrm{SS}$; $11=50 \% \mathrm{P}+50 \% \mathrm{DE} ; 12=75 \% \mathrm{P}+25 \% \mathrm{DE} ; 13=75 \% \mathrm{P}+25 \% \mathrm{SS} ; 14=100 \% \mathrm{P}$ (Control); and $15=100 \% \mathrm{DE}$

* Lowercase letters in columns show differences between substrates added mixtures showed the best QI values. The highest QI values were observed in $3^{\text {rd }}, 1^{\text {st }}$, and $9^{\text {th }}$ mixtures. As compared with the control ( $14^{\text {th }}$ mixture), these mixtures increased QI in the rates of $129.7 \%, 100 \%$, and $78.4 \%$, respectively. The effects of substrate mixture on QI showed the same tendency with other parameters investigated.

To evaluate the land performance of Scots pine seedlings grown in different substrates, a trial was established between the years 2013-2017 in Sarıkamış, Kars. Land performance of Scots pine seedlings (Pinus sylvestris L.) grown on different substrates are presented in Table 3. Survival rates and height and stem diameter of seedlings varied significantly. The survival rate of Scots pine seedlings varied between $65 \%-96 \%$. The highest survival rates were observed in $3^{\text {rd }}, 6^{\text {th }}, 10^{\text {th }}, 14^{\text {th }}, 9^{\text {th }}$, and $4^{\text {th }}$ mixtures. The highest plant height and stem diameters were observed in the $9^{\text {th }}$ and $3^{\text {rd }}$ mixtures, respectively. As compared with the control ( $14^{\text {th }}$ mixture), the $9^{\text {th }}$ mixture increased plant height and stem diameter in the rates of $11 \%$ and $12.4 \%$, respectively. The composition of this substrate was $50 \% \mathrm{P}+50 \% \mathrm{SS}$.

\section{DISCUSSION RASPRAVA}

Results obtained have shown that even at low application rates ( $25 \%$ SS, $13^{\text {th }}$ and $10^{\text {th }}$ mixtures) sewage sludge increased seedling height significantly. The $\mathrm{C}: \mathrm{N}$ ratio of organic matter is an important index that shows how much nitrogen will be mineralized relative to the $\mathrm{CO}_{2}$ released by microorganisms (Ge et al. 2013). Organic amendments with high $\mathrm{N}$ contents and low $\mathrm{C}: \mathrm{N}$ ratios mineralize sufficient $\mathrm{N}$ to satisfy plant growth (Cordovil et al. 2005). The high rate of organic matter and $\mathrm{C}$ in sewage sludge is responsible for the increased growth of seedlings. Mineralization of sewage sludge may have led to a sufficiently fast release of nutrients to meet the seedling requirements. Epstein et al. (1978) have stated that anaerobically digested sludge gave $\mathrm{N}$ mineralization rates of $40-42 \%$ in 15 weeks. Sewage sludge application, due to its high organic matter and macro and micronutrient content, may have improved the composition of rhizosphere, thereby resulting in growth acceleration. Similar results were reported by Perez-Murcia et al. (2006) for broccoli, Tufekci et al. (2008) for Pinus brutia, Aslantas et al. (2013) for sour cherry, and Leila et al. (2017) for Eucalyptus camaldulensis.

The reason of increase in stem diameter can not only be related to high organic matter of sewage sludge and its $\mathrm{N}$, $\mathrm{P}$, and $\mathrm{K}$ content, but also to improved soil water holding capacity (Bramryd 2002; Angin and Yaganoglu 2009). Velayoudon et al. (2014) have stated that there is a linear relationship between plant growth and trunk diameter. Valdecantos et al. (2011) have shown that pines amended with liquid biosolids showed 6-11\% increases in stem diameter 
and root collar diameter, respectively. Increases in shoot and root density after the application of organic amendments have been demonstrated by several researchers (Fuentes et al. 2007; Tabari and Salehi 2009; Marron 2015).

One of the main factors that affect success in afforestation studies is the use of high-quality seedlings. As seen in Table 2 , the highest quality seedlings were determined in substrates mixed with sewage sludge. These results indicated that the application of sewage sludge to the substrate sustains its effect on the land also. The substrate aims to maximize the quality of seedlings with minimum input. Results obtained in this study demonstrate that the application of sewage sludge, in a proper ratio, can be an alternative that can help to reduce the amount of high priced peat content in substrates.

\section{CONCLUSION ZAKLJUČCI}

This study was undertaken to evaluate (a) the feasibility of reducing the peat content in substrates by replacing it with different amounts of diatomite and sewage sludge for Scots pine seedling (Pinus sylvestris L.) growth and (b) evaluation of the land performance of Scots pine seedlings grown in different substrates. Results obtained from this study have clearly shown that the application of sewage sludge to the substrate is an effective way not only to reduce peat content in the substrate but also to improve seedling quality. As a result of the evaluations made in terms of both seedling morphological characteristics and land performance; the best performance was determined in the $9^{\text {th }}(50 \% \mathrm{P}+50 \% \mathrm{SS})$ and $3^{\text {rd }}(75 \% \mathrm{SS}+25 \% \mathrm{DE})$ mixtures. The rates of sewage sludge in these mixtures were $50 \%$ and $75 \%$. The main problem in the usage of sewage sludge is heavy metals and soluble salts, which could accumulate in the soil. However, its usage in seedling stage can be an alternative to minimize potential hazards, because of its usage in relatively small amounts.

\section{ACKNOWLEDGEMENTS}

\section{ZAHVALA}

This study was supported by the Republic of Turkey, General Directorate of Forestry (01.1203.2013-2017).

\section{REFERENCES}

\section{LITERATURA}

- Aksakal, EL., I. Angin, T. Oztas, 2012: Effects of diatomite on soil physical properties. Catena 88: 1-5.

- Aksakal, EL., I. Angin, T. Oztas, 2013: Effects of diatomite on soil consistency limits and soil compactibility. Catena 101: 157-163.

- Angin, I., M. Kose, R. Aslantas, 2011: Effect of diatomite on growth of strawberry. Pakistan Journal of Botany 43(1): 573577.
- Angin, I., AV. Yaganoglu, 2009: Application of sewage sludge as a soil physical and chemical amendment. Ekoloji 19(73): 39-47.

- Aslantas, R., I. Angin, AO. Kobaza, 2013: Long-term effects of sewage sludge application on sour cherry (Prunus creasus L.). Israel Journal of Plant Sciences 61(1-4): 51-56.

- Bramryd, T., 2002. Impact of sewage sludge application on the long-term nutrient balance in acid soils of Scots pine (Pinus Sylvestris, L.) forests. Water Air and Soil Pollution 140(1-4): 381399.

- Cordovil, CMdS., J. Coutinho, M. Goss, F. Cabral, 2005: Potentially mineralizable nitrogen from organic materials applied to a sandy soil: fitting the one-pool exponential model. Soil Use and Management 21: 65-72.

- Csaba, I., 1995: Growing medium in hydroculture. Plasticulture 108(4): 45-47.

- Dickson, A., AL. Leaf, JF. Hosner, 1960: Quality appraisal of white spruce and white pine seedling stocks in nurseries. The Forestry Chronicle 36: 10-13.

- Epstein, E., 2003: Land application of sewage sludge and biosolids. CRC Press, Boca Raton, Florida. 216 p.

- Epstein, E., DB. Keane, JJ. Meisinger, 1978: Mineralization of nitrogen from sewage sludge and sludge compost. Journal of Environmental Quality 7: 217-221.

- Fuentes, D., A. Valdecantos, J. Cortina, VR. Vallejo, 2007: Seedling performance in sewage sludge-amended degraded Mediterranean woodlands. Ecological Engineering 31(4): 281-291.

- Ge, S., H. Xu, M. Ji, Y. Jiang, 2013: Characteristics of soil organic carbon, total nitrogen, and $\mathrm{C} / \mathrm{N}$ ratio in Chinese apple orchards. Open Journal of Soil Science 3: 213-217.

- IBM, 2011: IBM Statistics for Windows, Version 20.0. IBM Corporation, Armonk, New York.

- Ingelmo, F., R. Canet, M.A. Ibañez, F. Pomares, J. García, 1998: Use of MSW compost, dried sewage sludge and other wastes as partial substitutes for peat and soil. Bioresource Technology 63: 123-129.

- Ingram, DL., RW. Henley, TH. Yeager, 2003: Growth Media for Container Grown Ornamental Plants (BUL 241). Environmental Horticulture Department, Florida Cooperative Extension Service, Institute of Food and Agricultural Sciences, University of Florida. $18 \mathrm{p}$.

- Jayasinghe, GY., Y. Tokashiki, ID. Liyana Arachchi, M. Arakaki, 2010: Sewage sludge sugarcane trash based compost and synthetic aggregates as peat substitutes in containerized media for crop production. Journal of Hazardous Materials 174: 700-706.

- Khraisheh, MAM., YS. Al-degs, WAM. Mcminn, 2004: Remediation of wastewater containing heavy metals using raw and modified diatomite. Chemical Engineering Journal 99: 177-184.

- Leila, S., M. Mhamed, H. Hermann, K. Mykola, W. Oliver, M. Christin, O. Elena, B. Nadia, 2017: Fertilization value of municipal sewage sludge for Eucalyptus camaldulensis plants. Biotechnology Reports 13: 8-12.

- Loeppert, RH., DL. Suarez, 1996: Carbonate and gypsum. In: Sparks, DL. [ed.]: Methods of soil analysis, Part 3, Chemical methods. SSSA Inc., Madison, WI, pp. 437-474.

- Marron, N., 2015: Agronomic and environmental effects of land application of residues in short-rotation tree plantations: A literature review. Biomass and Bioenergy 81: 378-400.

- Méndez, A., E. Cárdenas-Aguiar, J. Paz-Ferreiro, C. Plaza, G. Gascó, 2017: The effect of sewage sludge biochar on peat-based 
growing media. Biological Agriculture and Horticulture 33(1): 40-51.

- Nelson, DW., LE. Sommers, 1996: Total carbon, organic carbon, and organic matter. In: Sparks, DL. [ed.]: Methods of soil analysis, Part 3, Chemical methods. SSSA Inc., Madison, WI, pp. 961-1010.

- Olympios, CM., 1999: Overview of soilless culture: Advantages, constraints and perspectives for its use in Mediterranean Countries. Cahiers Options Méditerranéennes 31: 307-324.

- Perez-Murcia, MD., R. Moral, J. Moreno-Caselles, A. Perez-Espinosa, C. Paredes, 2006: Use of composted sewage sludge in growth media for broccoli. Bioresource Technology 97: 123-130.

- Pinamonti, F., G. Stringari, G. Zorzi, 1997: Use of compost in soilless cultivation. Compost Science \& Utilization 5(2): 38-45.

- Raviv, M., Y. Chen, Y. Inbar, 1986: Peat and peat substitutes as growth media for container-grown plants. In: Chen, Y., Y. Avnimelech [eds.]: The Role of Organic Matter in Modern Agriculture. Martinus Nijhoff Publishers, Dordrecht, pp. 257-287.

- Rhoades, JD., 1996: Salinity: electrical conductivity and total dissolved solids. In: Sparks, DL. [ed.]: Methods of soil analysis, Part 3, Chemical methods. SSSA Inc., Madison, WI, pp. 417-435.

- Tabari M., A. Salehi, 2009: Long-term impact of municipal sewage irrigation on treated soil and black locut trees in a semi-arid suburban area of Iran. Journal of Environmental Sciences 21(10): 1438-1445.

- Thomas, GW., 1996. Soil pH and soil acidity. In: Sparks, DL. [ed.]: Methods of soil analysis, Part 3, Chemical methods. SSSA Inc., Madison, WI, pp. 475-490.

- Tufekci, S., AG. Gulbaba, F. Tokgonul, 2008: Production of fast growing tree species seedlings using sewage sludge from TarsusCity domestic wastewater treatment plant (in Turkish). Cevre ve Orman Bakanligi Yayin No: 368, Tarsus, Turkey. 85 p

- USGS, 2008: USGS Minerals Information-Diatomite. United States Geological Survey Web. [Accessed 17 February 2019]. http://minerals.usgs.gov/minerals/pubs/commodity/ diatomite/\#pubs

- Valdecantos, A., J. Cortina, VR. Vallejo, 2011: Differential field response of two Mediterranean tree species to inputs of sewage sludge at the seedling stage. Ecological Engineering 37(9): 13501359.

- Velayoudon, P., P. Pagand, P. Winterton, M. Guiresse, 2014: Sewage sludge application for spontaneous plant restoration of a New Caledonian Ferralsol. Soil Research 52: 76-86.

- Wu, J., YS. Yang, J. Lin, 2005: Advanced tertiary treatment of municipal wastewater using raw and modified diatomite. Journal of Hazardous Materials 127(1-3): 196-203.

\section{SAŽETAK}

Unatoč tome što se supstratu za uzgoj dodaju određeni organski i anorganski supstrati kako bi se poboljšale njegove fizičke i kemijske karakteristike, i dalje je zanimljiva potreba za istraživanjem novih materijala i/ili smjesa koje smanjuju udio skupocijenog treseta u supstratima. $U$ ovom radu procijenit će se izvedivost smanjenja sadržaja treseta u supstratima njegovom zamjenom s različitim količinama diatometa i mulja iz otpadnih voda za rast sadnica običnog bora (Pinus sylvestris L.) te njihovo preživljavanje na terenu. Kako bi se procijenila izvedivost smanjenja sadržaja treseta u supstratima zamjenom $s$ različitim količinama diatometa i mulja iz otpadnih voda, provedeno je istraživanje u stakleniku, pod prirodnim svjetlom i u kontroliranim temperaturnim uvjetima. Između 2013. i 2017. godine u mjestu Sarıkamış, Kars (SI Anadolija) pokrenuto je istraživanje kojim će se procijeniti učinak koje zemljište ima na sadnice običnog bora koje rastu u različitim supstratima. Visoko organske tvari te makro i mikrohranjivi sastojci koji se nalaze u mulju iz otpadnih voda poboljšali su sastav rizosfere. što je rezultiralo bržim rastom sadnica. Kao rezultat evaluacija obavljenih u pogledu morfoloških karakteristika sadnica i utjecaja koji zemljište ima na preživljavanje sadnica; najbolji učinak postignut je u $9 .(50 \% \mathrm{P}+50 \% \mathrm{SS})$ i 3 . smjesi $(75 \% \mathrm{SS}+25 \% \mathrm{DE})$.

KLJUČNE RIJEČI: Mulj iz otpadnih voda, diatomit, treset, obični bor, morfološka svojstva, preživljavanje sadnica na terenu 